\title{
Analysis of Chemical Properties of Forest Soils in Dobrogea Plateau
}

\author{
VLAD EMIL CRISAN*, LUCIAN CONSTANTIN DINCA \\ National Institute for Research and Development in Forestry Marin Dracea, 13 Closca Str, 500040, Brasov
}

This paper aims to describe and interpret the chemical properties of forest soils in the Dobrogea Plateau. Data on soil analyzes are obtained in the laboratories of National Institute of Research and Development in Silviculture "Marin Dracea" after a recognized and accredited national and international methodology. There were analyzed soil reaction, base saturation degree, total cationic exchange capacity, humus content, total nitrogen and compared with results of soil analysis from other geographical regions of Romania. In the case of forest soils in Dobrogea Plateau, a higher $\mathrm{pH}$ was found than in other hilly or highland areas in the country to eutric cambisol, luvisol and preluvisol. Thus soil pH ranges from moderately acidic in the case of luvisols to low alkaline in the case of chernozems. Regarding the base saturation degree (V), there are higher values in this part of the country for preluvisol, luvisol and eutric cambisol and slightly lower values for phaeozem than in other regions of Romania. The amount of humus of eutric cambisols from Dobrogea Plateau is smaller than other hilly areas of the country and slightly higher than similar altitude areas.

Keywords: forestry soils, Dobrogea Plateau, soil solution reaction, humus.

The Dobrogea plateau is made up of several plateaus that overlap largely over the Dobrogea historical and geographical province [1]. The surface of this plateau is about $10400 \mathrm{~km}^{2}$, meaning $4.3 \%$ of Romania's territory and is morphologically characterized by low altitudes given that only a few peaks in the northwest exceed $400 \mathrm{~m}$ height and almost $90 \%$ of the surface is less than $200 \mathrm{~m}$ height (figure 1).

It is known that acidic soils contamination favor the increasing of the mobility of heavy metal ions and lead to soil degradation by exceeding the values for heavy metal content up to about $100 \mathrm{~cm}$ [2]. In this case, in Dobrogea Plateau there are not so many acidic soils, most of luvisol beeing moderatley acidic.

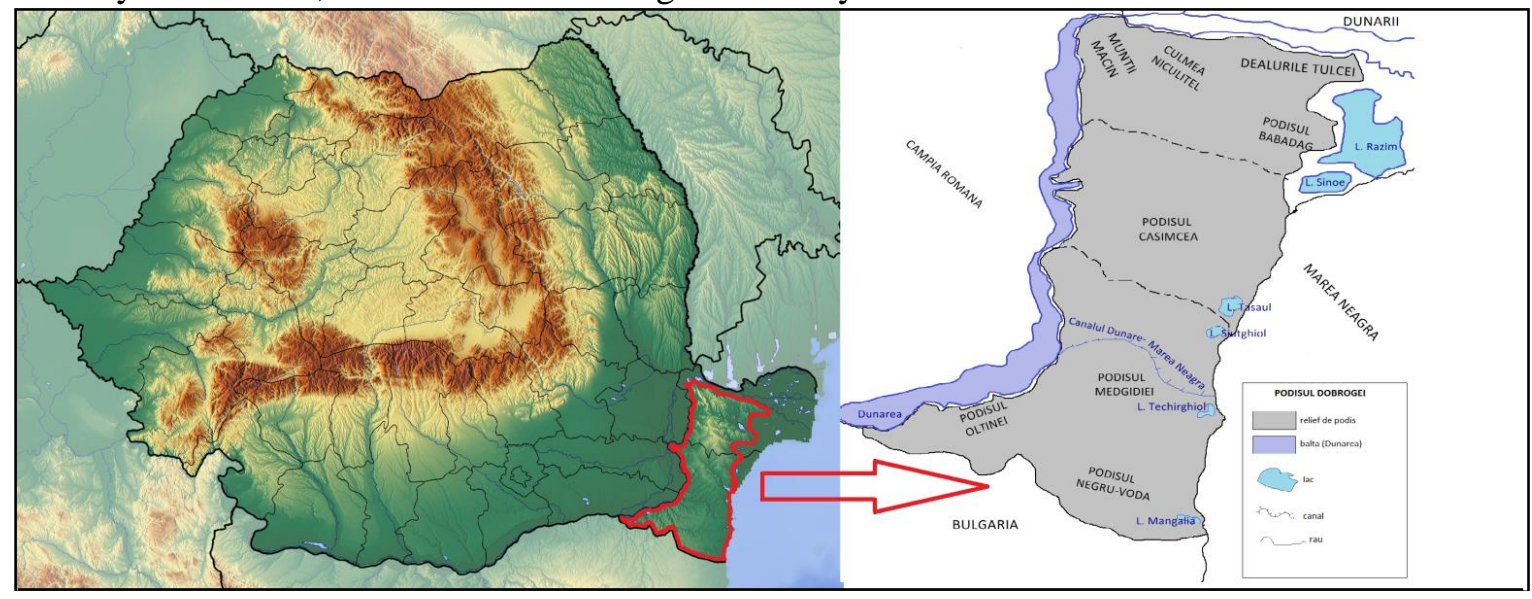

\section{Experimental part}

Fig. 1. Romania - Dobrogea Plateau

In Romania, the forests are managed on the base of forest management plans. This plans are made once at 10 years period. Forest engineers are measuring surface of the all forest from the district that is analyzed and they are making measurements of trees like composition, age structure, foliar characteristics and so on. But they are making also soil profiles, take soil samples and send them to laboratory in order to know what kind of soils are in that district. The methods used in the analysis of soil samples are the accredited national and international methods [3]. In the laboratories there are

\footnotetext{
*email:vlad_crsn@yahoo.com
} 
analyzed chemical properties like $\mathrm{pH}$, humus content, carbonates content, basis exchange capacity (Sb), hydrogen exchange capacity (Sh), total cationic exchane capacity $(\mathrm{T})$, base degree saturation $(\mathrm{V})$, texture, total nitrogen.

For this paper, it was analyzed chemical properties of the soil samples gathered in the period of the last 30 years from Dobrogea Plateau respectively 1988 - 2016 [4]. Soil profiles have been made in 10 forest districts: Babadag, Baneasa, Cernavoda, Harsova, Babadag, Casimcea, Cerna, Ciucurova, Macin, Niculitel. From these districts, there were analyzed 434 soil profiles and 1166 pedo-genetical horizons (samples). Average values for soil chemical parameters were calculated, the values differentiated by soil types and pedo-genetic horizons being distributed according to normal curves.

\section{Results and discussions}

Soil solution reaction $(\mathrm{pH})$

The average soil solution reaction, soil $\mathrm{pH}$ value of the Dobrogea Plateau for soil horizon A exceeds the value of 6 (figure 2) and is higher than in areas in the western part of the country such as West Plain, Bihor county or the centralsouthern part respectively counties Giurgiu, Arges, Buzau [5-7] (Table 1). For horizon B of the soil, the mean value of the $p \mathrm{H}$ is 6.25 . Highest $p \mathrm{H}$ values are found in chernozem, followed by eutric cambisol, and luvisol.

Luvisol is a spreading soil predominantly in the plain and hill area, but it can also occur in the lower mountain range. The Ao horizon generally has a thickness of $15-25 \mathrm{~cm}$, and a brown-brown / light-colored, granular structure. The average value of $p \mathrm{H}$ in this horizon is 6.33 and is higher than in studies targeting other areas in Romania. Thus, in the areas of western counties like Timisoara, Arad, Bihor as well as in Giurgiu, Arges and Buzau counties (figure 3), the soil solution reaction in this first horizon of the profile is moderately acidic, unlike the case in which we find a weakly acidic reaction [5-8].

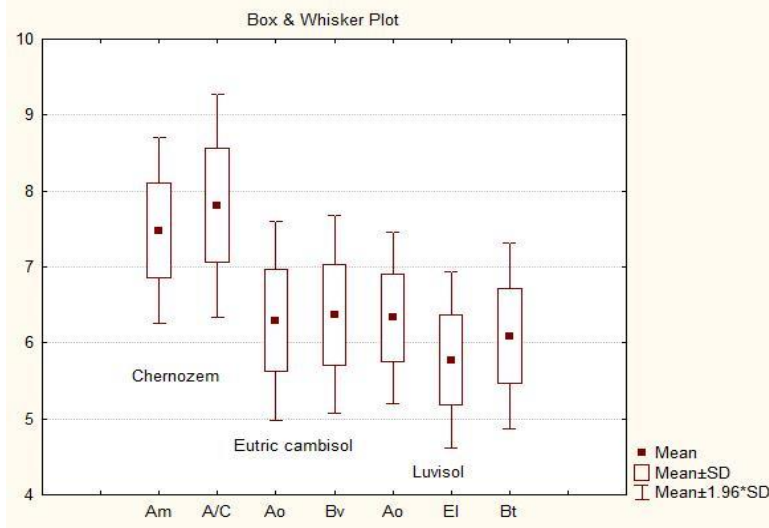

Fig. 2. $p \mathrm{H}$ variation of genetic horizons for the most widespread forest soils in Dobrogea Plateau

Table 1

SOIL SOLUTION REACTION $(p H)$ OF FOREST SOILS IN DIFFERENT PARTS OF ROMANIA

\begin{tabular}{|c|c|c|c|c|c|c|c|c|c|c|}
\hline \multirow[t]{2}{*}{ Area } & \multicolumn{2}{|c|}{ Chernozem } & \multicolumn{3}{|c|}{ Luvisol } & \multicolumn{2}{|c|}{ Preluvisol } & \multicolumn{2}{|c|}{ Eutric cambisol } & Reference \\
\hline & Am & $\mathrm{A} / \mathrm{C}$ & Ao & EI & Bt & Ao & $\mathbf{B t}$ & Ao & Bv & \\
\hline Dobrogea Plateau & 7.48 & 7.81 & 6.33 & 5.77 & 6.09 & 6.24 & 6.25 & 6.30 & 6.38 & \\
\hline West Plain & - & - & 5.23 & 5.01 & 5.48 & 5.06 & 5.64 & 4.99 & 5.33 & Dinca et al \\
\hline Girgiu County & 7.53 & 8.12 & 5.59 & 5.33 & 5.71 & 5.62 & 5.89 & - & - & Crisan et al., 2016 \\
\hline Bihor County & - & - & 5.12 & 4.96 & 5.38 & 4.88 & 5.32 & 5.48 & 5.69 & Dinca et al., 2017 \\
\hline Arges County & - & - & 5.17 & 4.89 & 5.22 & 4.9 & 5.26 & 5.19 & 5.47 & Enescu C.M. et al., 2018 \\
\hline Buzau County & 6.98 & 7.82 & 5.64 & 5.11 & 5.67 & 5.26 & 5.5 & 5.44 & 5.89 & Crisan et al., 2018 \\
\hline
\end{tabular}




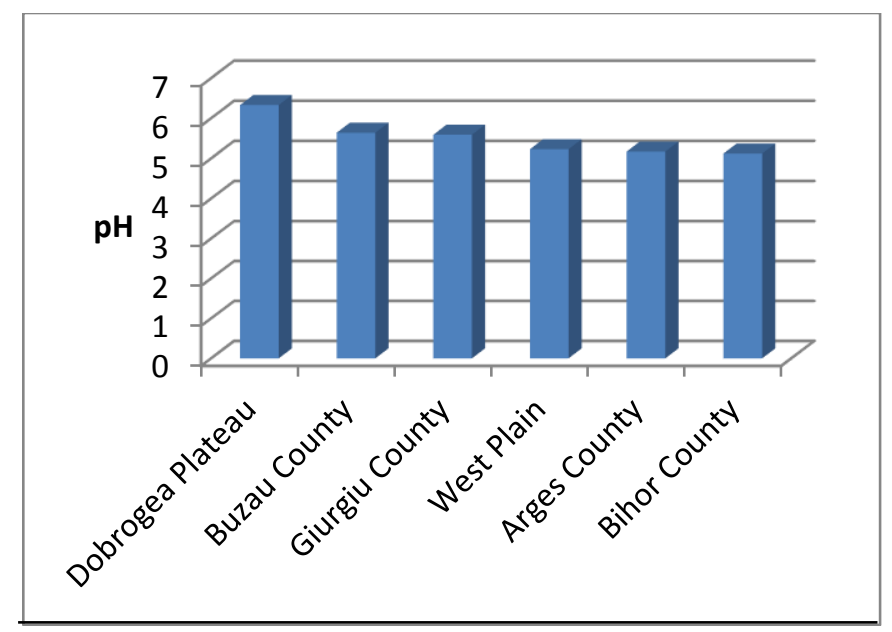

Fig. 3. $p \mathrm{H}$ variation in the Ao horizon from luvisols in different parts of Romania

Base saturation degree (V)

Regarding base saturation degree, the values for the phaeozem in the Dobrogea Plateau (figure 4) confirm that it is an eubazic soil and its values are closer to those of phaeozems in other plains [9- 11] (table 2).

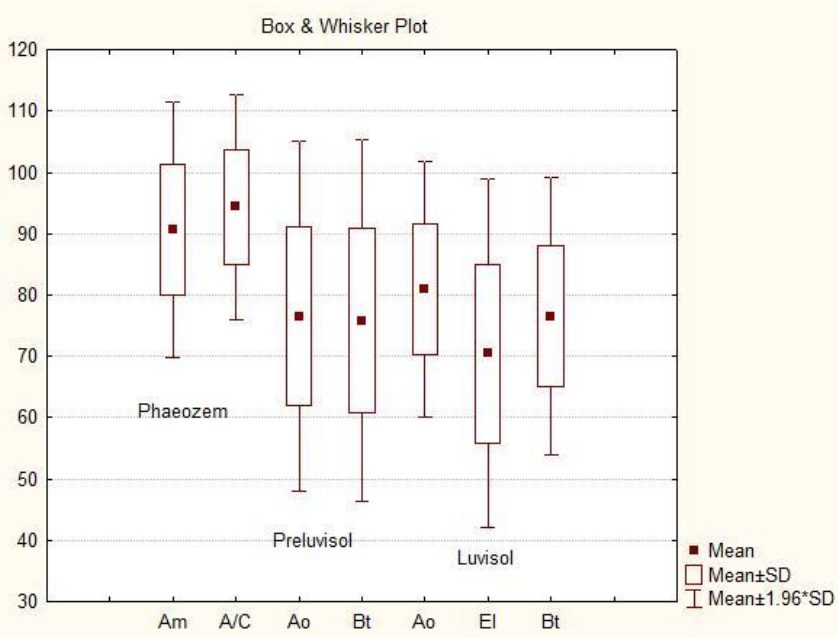

Fig.4. Base saturation degree (V) variation of genetic horizons for the most widespread forest soils in Dobrogea Plateau

Analyzing the values of the other types of soils (Table 2) it was found that the values of the first horizon Ao of the eutric cambisol, preluvisol and luvisol are higher than the values of the same soils in other parts of the country [9-11].

Table 2

BASE SATURATION DEGREE FOR FOREST SOILS IN DIFFERENT PARTS OF THE ROMANIA

\begin{tabular}{|c|c|c|c|c|c|c|c|c|c|c|}
\hline \multirow[t]{2}{*}{ Area } & \multicolumn{2}{|c|}{ Phaeozem } & \multicolumn{2}{|c|}{$\begin{array}{c}\text { Eutric } \\
\text { cambisol }\end{array}$} & \multicolumn{2}{|c|}{ Preluvisol } & \multicolumn{3}{|c|}{ Luvisol } & \multirow[t]{2}{*}{ Reference } \\
\hline & Am & $\mathrm{A} / \mathrm{C}$ & Ao & Bv & Ao & $\mathbf{B t}$ & Ao & El & Bt & \\
\hline Dobrogea Plateau & 90.66 & 94.34 & 79.60 & 80.12 & 76.49 & 75.76 & 80.90 & 70.43 & 76.57 & \\
\hline West Plain & 90.13 & 98.87 & 60.56 & 71.81 & 56.71 & 72.38 & 59.24 & 50.37 & 67.19 & Dinca \\
\hline Cluj County & 94.48 & 99.1 & 62.11 & 68.75 & 55.28 & 66.77 & 61.55 & 50.63 & 61.02 & Enescu R \\
\hline Olt County & 89.66 & 95.57 & - & - & 60.55 & 74.07 & 66.41 & 59.51 & 73.3 & Deleanu \\
\hline Harghita County & 97.2 & 98.3 & 62.32 & 73.91 & 65.15 & 76.69 & 62.18 & 53.3 & 66.25 & Enescu R \\
\hline Arad County & 91.11 & 99.01 & 62.92 & 70.92 & 55.52 & 67.09 & 53.76 & 48.4 & 59.85 & Cantar \\
\hline
\end{tabular}


Total cationic exchange capacity $(T)$

If the total cationic exchange capacity is analyzed then the three soil types with the values between 15 and 25 miliequivalents per 100 grams of soil, respectively eutric cambisol, luvisol and preluvisol have a high total cationic exchange capacity and chermozem and phaeozem have a very high values of total cationic exchange capacity with values exceeding 25 miliequivalents per 100 grams of soil (table 3 and figure 5).

Table 3

AVERAGE CONTENT OF CHEMICAL PROPERTIES OF FOREST SOILS IN DOBROGEA PLATEAU

\begin{tabular}{|c|c|c|c|c|}
\hline Chernozem & Phaeozem & Eutric cambisol & Luvisol & Preluvisol \\
\hline \multicolumn{5}{|l|}{ pH } \\
\hline 7.65 & 7.42 & 6.34 & 6.07 & 6.25 \\
\hline \multicolumn{5}{|c|}{ Base saturation degree (\%) } \\
\hline 97.44 & 92.70 & 79.92 & 75.95 & 76.04 \\
\hline \multicolumn{5}{|c|}{ Total average cationic exchange capacity per soil type (T-me $\left.100 \mathrm{~g}^{-1} \mathrm{sol}\right)$} \\
\hline 33.87 & 27.82 & 24.74 & 24.87 & 24.32 \\
\hline \multicolumn{5}{|c|}{ Average humus content in the A horizon per soil type (H-\%) } \\
\hline 4.71 & 5.20 & 4.77 & 5.82 & 5.52 \\
\hline \multicolumn{5}{|c|}{ Average nitrogen content in the A horizon per soil types (\%) } \\
\hline 0.26 & 0.27 & 0.24 & 0.30 & 0.28 \\
\hline
\end{tabular}

Total cationic exchange capacity $(\mathrm{T})$ of the eutric cambisol, luvisol and preluvisol in the Dobrogea Plateau is similar to that in other counties of the country $[9,12,5,13,10]$ (table 4$)$.

Table 4

TOTAL CATIONIC EXCHANGE CAPACITY OF FOREST SOILS IN DIFFERENT PARTS OF ROMANIA

\begin{tabular}{|l|l|l|l|l|}
\hline Area & $\begin{array}{l}\text { Eutric } \\
\text { cambisol }\end{array}$ & Luvisol & Preluvisol & Reference \\
\hline Dobrogea Plateau & 24.74 & 24.87 & 24.32 & \\
\hline West Plain & 19.08 & 24.51 & 24.18 & Dinca \\
\hline Timis County & 20.33 & 22.97 & 23.30 & Crisan \\
\hline Maramures County & 25.61 & 21.14 & 20.61 & Crisan \\
\hline Iasi County & 20.72 & 21.07 & 21.30 & Dinca \\
\hline Harghita County & 26.57 & 25.79 & 27.64 & Enescu R \\
\hline
\end{tabular}

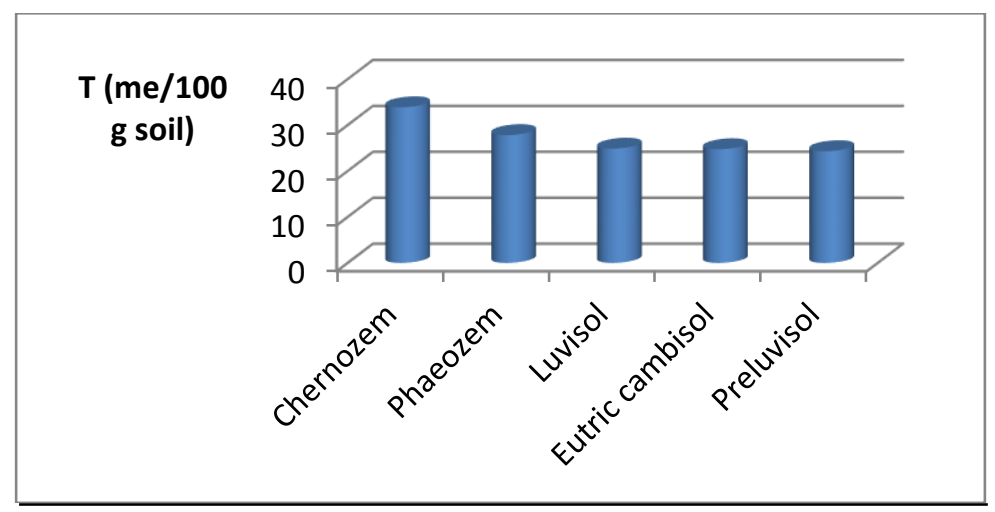

Fig. 5. The variation of total cationic exchange capacity for the most widespread forest soils in Dobrogea Plateau 


\section{Humus content}

The amount of humus that matter and varies between the soil types is the one from the first horizon, and its average values for the different soil types in the analyzed area have been calculated (figure 6). The eutric cambisol and chernozem in Dobrogea Plateau are moderately humiferous, while luvisols (5.82\%) and preluvisols (5.52\%) are intensely humiferous, their values in horizon A surpassing 5\% humus content. In Dobrogea Plateau phaeozem contain more than 5\% humus $(5.20 \%)$ this characteristic beeing found also in phaeozem in Suceava Plateau where analitical data show that these soils are very rich in humus [14]. Instead eutric cambisol in agriculture lands from North-west part of the Cracau-Bistrita depresion is poor in humus and nutrients and low fertility [15].

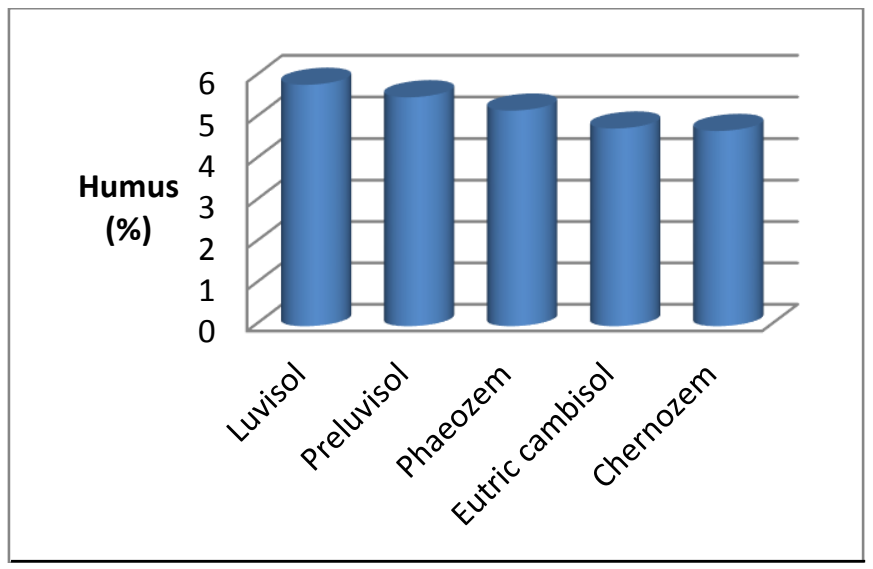

Fig. 6. The variation of humus content in A horizon for the most widespread forest soils in Dobrogea Plateau

Similar values of humus were found for phaeozem, eutric cambisol and luvisol in the country [9, 16, 7, 10,]. The amount of humus in the preluvisol is slightly higher than that of the county of Caras-Severin or the Western Plain.

Table 5

HUMUS CONTENT OF FOREST SOILS IN DIFFERENT PARTS OF ROMANIA

\begin{tabular}{|l|l|l|l|l|l|}
\hline Area & Phaeozem & $\begin{array}{l}\text { Eutric } \\
\text { cambisol }\end{array}$ & Luvisol & Preluvisol & Reference \\
\hline Dobrogea Plateau & 5.20 & 4.77 & 5.82 & 5.52 & \\
\hline West Plain & 4.19 & 4.26 & 5.4 & 5.06 & Dinca \\
\hline Caras County & - & 6.57 & 6.08 & 5.34 & Dinca M \\
\hline Vaslui County & 3.68 & 4.08 & 4.81 & 4.0 & Dinca M \\
\hline Buzau County & 5.7 & 5.61 & 5.87 & 4.99 & Crisan \\
\hline Cluj County & 5.58 & 4.56 & 4.3 & 4.1 & Enescu $\mathrm{R}$ \\
\hline Prahova County & - & 6.65 & 6.08 & - & Enescu M \\
\hline
\end{tabular}




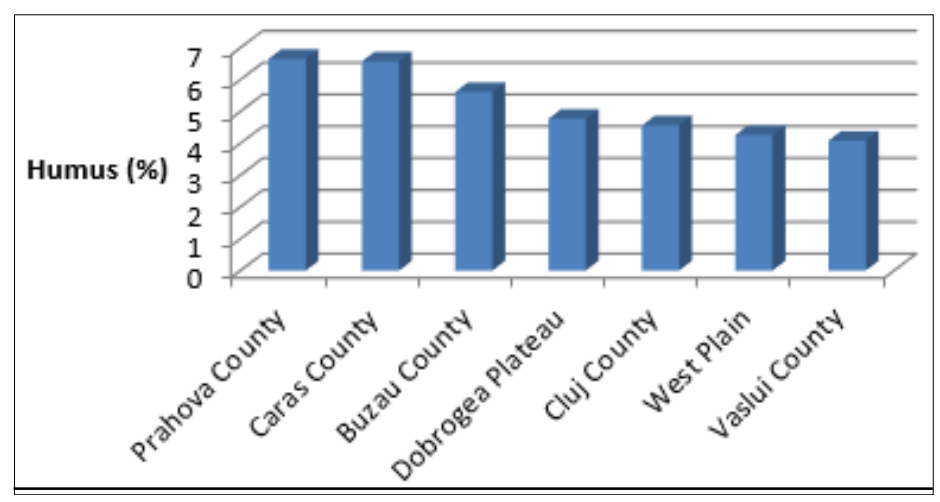

Fig. 7. Humus variation in eutric cambisol in different parts of Romania

Analyzing the variation of humus only in the case of eutric cambisol (figure 7), we find that values from Dobrogea Plateau (4.77\%) is situated closer to the plain areas of the country such as Cluj county $(4.56 \%)$, Western Plain $(4.26 \%)$, Vaslui County $(4.08 \%)[10,9]$ than hilly areas such as Prahova $(6.65 \%)$, Caras county $(6.57 \%)$ or Buzau county $(5.61 \%)$ $[16,7]$.

\section{Total nitrogen}

The soils in this area are well supplied with nitrogen. Values are ranging between $0.2 \%$ and $0.28 \%$ nitrogen concentration in the first horizon with $0.24 \%$ for eutric cambisol, $0.26 \%$ for chernozem, $0.27 \%$ phaeozem, $0.28 \%$ preluvisol and even $0.30 \%$ for luvisol.

\section{Conclusions}

The forest soils in Dobrogea Plateau are soil specific to the plain areas, being moderate to low acid in the case of luvisol, low acid in the case of eutric cambisols and low alkaline in the case of chernozem, with total cationic exchange capacity from high to very high, intensely humid and well supplied with nitrogen.

Most soil types occur in other geographic areas of Romania and have different chemical properties due to differences in altitude, geology and geomorphology. In the case of forest soils in Dobrogea Plateau, a higher $\mathrm{pH}$ was found than in other hilly or high areas in the country to eutric cambisol, luvisol and preluvisol.

Concerning the base saturation degree $(\mathrm{V})$, there are higher values in this part of the country for preluvisol, luvisol and eutric cambisol and slightly lower values for phaeozem than in the rest of the analyzed regions. The amount of humus of eutric cambisols from Dobrogei Plateau is smaller than other hilly areas of the country and slightly higher than similar altitude areas.

\section{References}

1.IELENICZ, M., Anal. Univ. Valahia Targoviște, Ser. Geogr., 3, 2003, p. 51.

2.GHEORGHE, M., POPESCU, G. L., PRODAN, D., COJOCARU, I., GROZA, M., REV.CHIM., 70, No. 3, 2019 , p. 801.

3. DINCĂ, L., LUCACI, D., IACOBAN C., IONESCU M., Metode de analiza a proprietatilor si solutiei solurilor, Editura Tehnica Silvica, 2012, p. 173.

4. Forest Management Plans: Babadag (2014), Baneasa (1996, 2006, 2016), Cernavoda (1995, 2005, 2015), Harsova (2004, 2009), Babadag (2015), Casimcea (1988, 1998, 2008), Cerna (1992, 2002, 2012), Ciucurova (2004, 2014), Macin (1996, 2006, 2016), Niculitel (1992, 2002, 2012).

5. CRIȘAN, V.E., ENESCU, R.E., DINCÄ, L., Rev. Silv. Cineg., nr.39, 2016, p. 85

6. ENESCU, C.M., DINCĂ, L., 2018. Cur. Tr. Nat. Scie., 7, 14, p. 176.

7. CRISAN, V.E., ENESCU, R. E., BRAGA, C., Jou. Hort. For. Bio., 21, 3, 2017, p. 142.

8. DINCĂ, L., ONET, A., ENESCU, R., PANTEA, E., ROMOCEA, T., TIMIS-GÂNSAC, V., Nat. Res. Sust. Dev., 2017, p. 35.

9. DINCĂ, L., CHISĂLIȚĂ, I., CÂNTAR, I.C., Rev. Chim. 70, 7, 2019, p. 2372.

10. ENESCU, R.E., DINCĂ, L., LUCACI, D., ProEnvir., 10, 30, 2017, p. 57.

11. CÂNTAR I. C., DINCĂ L., Ann. Univ. Craiova, Ser. Bio. Hort., Envi. eng., 23, LIX, 2018, p. 5

12. CRIȘAN, V., DINCĂ, L., Jou. Hort. For. Biotech., Vol 21, 3, 2017, p. 137.

13. DINCĂ, L., DINCĂ, M., Lucr. şt. USAMV Iasi, ser. Hort., 60, 1, 2017, p. 249.

14. STANILA, A.-L., Rev. Chim., 70, no. 3, 2019, p. 909.

15. STANILA, A.-L., SIMOTA, C. C., DUMITRU, M., DUMITRU, S. I., IGNAT, P., Rev. Chim., 70, no. 4, 2019 , p. 1178.

16. ENESCU, C.M., DINCĂ, L., BRATU, I.A., Scien. Pap. Ser. Manag., Ec. Eng. Agr. Rur. Dev., Vol. 18, 4, 2018, p. 109.

Manuscript received: 13.06 .2019 